\title{
Economic Analysis of the Cotton Industry in Cote d'Ivoire
}

\author{
Dr. Kouakou Kouakou Paul-Alfred \\ University Peleforo GON COULIBALY, Republic
}

Doi: 10.19044/elp.v5no3a2

URL:http://dx.doi.org/10.19044/elp.v5no3a2

\begin{abstract}
This study aims at assessing the competitiveness of the cotton industry in Cote d'Ivoire. The survey involved two hundred and eighty-nine (289) producers, four (04) ginning companies, one (01) spinning company, two (02) crushing companies and seven (07) management structures of the sector. The data were analyzed using Monke and Pearson's (1989) Policy Analysis Matrix (PAM). Results show that the cotton industry is competitive and has a comparative advantage. The different actors achieve economic and financial profitability. The cotton industry is protected by the agricultural policy of Cote d'Ivoire. Each link has joint protection on the price of outputs and tradable inputs and also an implicit subsidy.
\end{abstract}

Keywords: Cotton, PAM, profitability, competitiveness, Cote d'Ivoire.

\section{Introduction}

Cote d'Ivoire is a country in West Africa that has two ecological zones in terms of vegetation. It is the forest located in the Southern part and the Savannah found in the north of the country. The economy, based mainly on agriculture, has relied on these ecological zones to develop agricultural speculations. Thus, in the southern forest, there has been a cacoa-coffee pairing, which accounts for almost $20 \%$ of the Gross Domestic product (GDP) and $40 \%$ of the export earnings. In the north, cotton cultivation has become essential and today a contribution of $1.7 \%$ in the GDP (Simplice, 2013). It remains one of the main sources of monetary income in the northern and central regions of the country.

Besides, it occupies more than 150000 producers and directly or indirectly feeds nearly 3.5 million of people. Cotton represents about $10 \%$ of the volume of exports and occupies the $3^{\text {rd }}$ place after the coffee and cocoa. In terms of results, the turnover of the cotton industry is between 100 and 120 billion of Franc CFA of which $70 \%$ to $80 \%$ in currency (Kouakou, 2014). 
It should be noticed, however, that the cotton sector is not immune to the effects of price declines on the international market in recent years. Better, to guarantee a minimum income to the producers, the State had to intervene several times to support the cotton industry by important financial contributions (Fabio, 2006).

Moreover, even if a great literature exists on cotton, one notices a lack of study on the competiveness of this sector. Then, this study will allow us to examine the profitability, competiveness and efficiency of the sector and also to evaluate the impact of agricultural policies.

Specifically, it will be to:

analyze the financial and economic profitability, the comparative advantage, the incitation measures put in place as well as the social gain generated by various subsectors of the cotton sector;

- $\quad$ measure the impact of government policies on private profitability ;

- estimate the current resource efficiency used in the different production systems ;

- $\quad$ evaluate the level of protection of the actors and determine the factors that influence the profitability and competiveness of the sector.

\section{I- Methodology}

\section{1-1 Study area}

The survey took place from May $25^{\text {th }}$ to June $30^{\text {th }}, 2017$. The choice of sites was made by taking into account the importance of the activity according to the data of the Intercoton (Structure responsible for the management of the cotton sector). So, on that basis, we chose the sub- prefectures of Kassere and Baya from the department of Boundiali for producers and Korhogo and Bouaké towns for ginning, spinning and crushing companies.

\section{1-2 Sampling}

The target population of our survey mainly included cotton producers, ginning, spinning and crushing companies, the organizations of management, of regulation and of the development of the cotton sector and professional agricultural organizations.

Our sampling consists of three hundred (300) actors of the sector distributed as follows: 289 producers, (04) ginning companies, (02) crushing companies, (01) spinning company and (07) framework structures and regulation of the sector. The number of seed cotton producers surveyed (289) is obtained on the basis of one-tenth of the total number of producers identified. This sample is chosen excessively with reference to the result obtained from the following formula:

$X i=n \cdot \frac{n i}{N}$ 
where:

$\mathrm{Xi}=$ number of producers to be surveyed per production area;

$\mathrm{n}=$ size of sampling;

$\mathrm{ni}=$ number of producers per production area;

$\mathrm{N}=$ total population of producers;

$X i=n \cdot \frac{n i}{N}=$ relative frequency.

The number of producers surveyed per site is recorded in the Table I.

Table I: Distribution of respondents per production areas

\begin{tabular}{|l|l|l|l|l|}
\hline Sites (Villages) & $\begin{array}{l}\text { ni (agricultural } \\
\text { production unit }\end{array}$ & ni/N & n.ni/N & $\begin{array}{l}\text { Xi (agricultural } \\
\text { production } \\
\text { listed) }\end{array}$ \\
surveyed)
\end{tabular}

\section{1-3 Data analysis method}

\section{Policy Analysis Matrix (PAM)}

In this study, the Policy Analysis Matrix (PAM) has been used for the analysis. That tool is commonly used in studies aiming at evaluating the impact of an economic policy on the efficiency of agricultural production systems. It is a double entry accounting system that allows you to evaluate the impact of the macroeconomic policies on producers and community incomes. The PAM is composed of two (2) types of budgets: a budget valued at private prices or financial prices and the other at social costs or economic costs.

Before the budget design, it is necessary to distinguish between tradable and domestic inputs. Tradable or marketable products are those which can be theoretically imported or exported while non-tradable products or domestic factors are those which are not normally tradable on international markets. In this case, with regard to exchangeable inputs, we can quote : the spray, the cart, the plow, fertilizers, phytosanitary products and the small material (hoe, sowing machine) for seed cotton producers; the fiber conditioning equipment (general compacter, fiber slides, humidification device, groomer feeder, groomer, hydraulic and strapping press / bagging), the 
seed cotton transport equipment( tractors, containers, poly skips), the seed cotton storage equipment (transport containers, compacted modules) and unloading systems (hydraulic telescopes, the module feeder) for the ginning; textile spinning machines consisting of cleaner-harvester or cleaning machine, carding, stretching or drawing and processing equipment such as the bleaching and dyeing for textile spinning and lastly the crushing equipment consisting of settling tanks, a system consisting of breaker or grinder, mixer, horizontal settling tanks and separator for the crushing. As for domestics inputs, it is the ground, manpower and capital for seed cotton producers ; of exploitation capital, financial costs, insurances, taxes, social charges, shops, staff costs, maintenance, security and training costs, energy for ginners, spinners and crushers.

Financial prices are those that actors pay or receive while economic prices reflect the cost of the economy and society. For determining the financial prices of rural labor, agricultural land and capital, the opportunity cost was estimated. Thus, for labor, the wages of agricultural laborers in times of intense activity was price as opportunity cost. For land, the rental cost has been taken as opportunity cost. As for the capital, the opportunity cost is that of the financial market. As the determination of economic prices is concerned, the principle is based essentially on a valuation of production factors and goods and services produced at international parity prices according to the module EASYpol 046 (FAO, 2005). Then, for all imported tradable, the parity price is the sum of the border price and shipping cost. As for exported goods or products, their parity price is the difference between the price of goods at the point of entrance, the CIF price and exit price of the country, the FOB. For the value-added elements of the operating account, we used standard conversion factors:

- $\quad$ labor costs: conversion factor equal to 1;

- $\quad$ transfers with State (taxes and subsidies): conversion factor equal to 0;

- $\quad$ social charges, financial costs and insurance: conversion factor equal to 0 ;

- $\quad$ elements of capital (technical and economic depreciation): conversion factor equal to 1 ;

- $\quad$ rental fees: conversion factor equal to 0;

- $\quad$ transport: conversion factor equal to 0.85 ;

- $\quad$ miscellaneous management fees: conversion factor equal to 0.96 ;

- $\quad$ expenditure on non-depreciable tools: conversion factor equal to 0.97.

The construction of the Policy Analysis Matrix was based on the prices observed in 2016. Tables II and III present respectively the model and competitiveness and economic efficiency indicators of the Policy Analysis Matrix (PAM). 
Table II: Policy Analysis Matrix (PAM)

\begin{tabular}{|l|l|l|l|l|}
\hline \multirow{2}{*}{} & \multirow{2}{*}{ Revenues } & \multicolumn{2}{|l|}{ Input cost } & \multirow{2}{*}{ Profit } \\
\cline { 3 - 4 } & & Tradable & Non-tradable & \\
\hline Private prices & A & B & C & D \\
\hline Social prices & E & F & G & H \\
\hline Net transfers & I=A-E & J=B-F & K=C-G & L=D-H \\
\hline
\end{tabular}

Source: Monke and Pearson (1989)

Table III: Competitiveness and economic efficiency indicators of the Policy Analysis Matrix (PAM)

\begin{tabular}{|ll|l|}
\hline $1-$ & Private profit & $\mathrm{D}=\mathrm{A}-\mathrm{B}-\mathrm{C}$ \\
\hline $2-$ & Private Cost Ratio & $\mathrm{PCR}=\mathrm{C} /(\mathrm{A}-\mathrm{B})$ \\
\hline $3-$ & Social profit & $\mathrm{H}=\mathrm{E}-\mathrm{F}-\mathrm{G}$ \\
\hline $4-$ & Domestic Resource Cost Ratio & $\mathrm{DRC}=\mathrm{G} /(\mathrm{E}-\mathrm{F})$ \\
\hline $5-$ & Social Cost Ratio & $\mathrm{SCR}=(\mathrm{F}+\mathrm{G}) / \mathrm{E}$ \\
\hline $6-$ & Transfer & $\mathrm{L}=\mathrm{I}-\mathrm{J}-\mathrm{K}$ \\
\hline $7-$ & Nominal Protection Coefficient & $\mathrm{NPC}=\mathrm{A} / \mathrm{E}$ \\
\hline $8-$ & Effective Protection Coefficient & $\mathrm{EPC}=(\mathrm{A}-\mathrm{B}) /(\mathrm{E}-\mathrm{F})$ \\
\hline $9-$ & Profitability Coefficient & $\mathrm{PC}=\mathrm{D} / \mathrm{H}$ \\
\hline $10-$ & Subsidy Ratio to Producers & $\mathrm{SRP}=\mathrm{L} / \mathrm{E}$ \\
\hline $11-$ & Equivalent Subsidy to producers & $\mathrm{ESP}=\mathrm{L} / \mathrm{A}$ \\
\hline
\end{tabular}

\section{II- $\quad$ Results and discussion}

\section{2-1 Competitiveness of the sub-sector of seed cotton production} Policy Analysis Matrix (PAM) of seed cotton producers

The analysis of the results in the Table IV indicates that private and economic profits are greater than 0 . The production of seed cotton is profitable for the producers of the department of Boundiali. It also contributes to the economic growth of the locality. Moreover, the sub-sector of seed cotton production has a comparative advantage and, as such, the country has every interest in encouraging this activity. Positive net transfers say economic prices are lower than what they currently receive. Then cotton producers in this area are subsidized. These results are similar to those of Hubert (2011).

Table IV: PAM for the production of one hectare of cotton

\begin{tabular}{|c|c|c|c|c|}
\hline & & Input cost & & \\
\hline & Revenue & Tradable inputs & $\begin{array}{l}\text { Non tradable } \\
\text { inputs }\end{array}$ & Profit \\
\hline Private prices & A 266325 & 134795 & $\begin{array}{ll}\mathrm{C} & \\
& 119805 \\
\end{array}$ & $\begin{array}{ll} & \\
& 11725 \\
\end{array}$ \\
\hline Social prices & $\begin{array}{l}\text { E } \\
246225 \\
\end{array}$ & 124198 & $\begin{array}{ll}\mathrm{G} & \\
& 115030 \\
\end{array}$ & $\begin{array}{|lr|}\mathrm{H} & \\
& 6997 \\
\end{array}$ \\
\hline Net transfers & $\begin{array}{ll}\text { I } & \\
& 20100 \\
\end{array}$ & $\begin{array}{ll}\mathrm{J} & \\
& 10597 \\
\end{array}$ & $\begin{array}{ll}\mathrm{K} & \\
& 4775\end{array}$ & \begin{tabular}{|ll}
$\mathrm{L}$ & \\
& 4728 \\
\end{tabular} \\
\hline
\end{tabular}




\section{Competitiveness and economic efficiency indicators of the Policy Analysis Matrix (PAM) of seed cotton production}

According to the results in the table V, the Private Cost Ratio (PCR), the Social Cost Ratio (SCR) and the Domestic Resource Cost Ratio (DRC) are less than 1 . The producers allocate their resources efficiently. As a result, the income from the cotton production activity is well above the expenditure. It is cheaper in domestic resources to produce cotton locally. The country should increase its exports in the cotton sector. The production activity is economically profitable. Domestic production is competitive. The cost of inputs is lower than the income generated by cotton. These same results also indicate that the production of cotton has an Effective Protection Coefficient (EPC) and a Nominal Protection (NPC) respectively greater than 1. The producers thus benefit from a subsidy of the order of $2 \%$. They are thus protected by the current Ivorian agricultural policy.

Table V: Competitiveness and economic efficiency indicators of the Policy Analysis Matrix (PAM) of seed cotton production

\begin{tabular}{|ll|l|l|}
\hline $1-$ & Private profit & $\mathrm{D}=\mathrm{A}-\mathrm{B}-\mathrm{C}$ & 11725 \\
\hline $2-$ & Private Cost Ratio & $\mathrm{PCR}=\mathrm{C} /(\mathrm{A}-\mathrm{B})$ & 0.91 \\
\hline $3-$ & Social profit & $\mathrm{H}=\mathrm{E}-\mathrm{F}-\mathrm{G}$ & 6997 \\
\hline $4-$ & Domestic Resource Cost Ratio & $\mathrm{DRC}=\mathrm{G} /(\mathrm{E}-\mathrm{F})$ & 0.94 \\
\hline $5-$ & Social Cost Ratio & $\mathrm{SCR}=(\mathrm{F}+\mathrm{G}) / \mathrm{E}$ & 0.97 \\
\hline $6-$ & Transfers & $\mathrm{L}=\mathrm{I}-\mathrm{J}-\mathrm{K}$ & 4728 \\
\hline $7-$ & Nominal Protection Coefficient & $\mathrm{NPC}=\mathrm{A} / \mathrm{E}$ & 1.08 \\
\hline $8-$ & Effective Protection Coefficient & $\mathrm{EPC}=(\mathrm{A}-\mathrm{B}) /(\mathrm{E}-\mathrm{F})$ & 1.09 \\
\hline $9-$ & Profitability Coefficient & $\mathrm{PC}=\mathrm{D} / \mathrm{H}$ & 1.68 \\
\hline $10-$ & Subsidy Ratio to Producers & $\mathrm{SRP}=\mathrm{L} / \mathrm{E}$ & 0.02 \\
\hline $11-$ & Equivalent Subsidy to producers & $\mathrm{ESP}=\mathrm{L} / \mathrm{A}$ & 0.02 \\
\hline
\end{tabular}

\section{2-2 Competitiveness of sub-sector of seed cotton ginning}

\section{Policy Analysis Matrix (PAM) of ginning companies}

The activity of ginning presents a financial profit higher than 0 . The sector of ginning is financially profitable (cf. Table VI). Moreover, with an economic return equal to 14318 FCFA / ton and greater than 0 , it can be said that this activity contributes to the economic growth of the locality and that it has a comparative advantage. The country has every interest in encouraging cotton processing. In addition, the analysis of the net transfer shows that the ginners are subsidized at 2067 FCFA / ton. This result is similar to that of Adegbola et al (2006). In the study conducted on the profitability of the cotton sector, this author came to the conclusion that the ginning function is profitable. 
Table VI: PAM of ginners for one ton of seed cotton

\begin{tabular}{|c|c|c|c|c|}
\hline & & Inputs cost & & \\
\hline & Revenue & Tradable inputs & Domestic factors & Profit \\
\hline Private prices & $\begin{array}{l}\text { A } \\
\quad 373860 \\
\end{array}$ & $\begin{array}{ll}\text { B } & \\
& 185705 \\
\end{array}$ & $\begin{array}{l}\mathrm{C} \\
171770 \\
\end{array}$ & $\begin{array}{ll}\mathrm{D} & \\
& 16255 \\
\end{array}$ \\
\hline Social prices & $\begin{array}{l}\text { E } 347730 \\
\end{array}$ & 169600 & \begin{tabular}{|ll}
$G$ & \\
& 163812 \\
\end{tabular} & 14318 \\
\hline Net transfers & I 26130 & $\begin{array}{ll}\mathrm{J} & \\
& 16105\end{array}$ & K 7958 & $\begin{array}{ll}\mathrm{L} & \\
& 2067\end{array}$ \\
\hline
\end{tabular}

\section{Competitiveness and economic efficiency indicators of the Policy Analysis} Matrix (PAM) of the ginning of seed cotton

The ginning subsector of the cotton sector has a Private Cost Ratio (PCR), a Domestic Resource Cost Ratio (DRC) and a Social Cost Ratio (SCR) of less than 1, respectively, according to the results in Table VII. The ginning is therefore a financially and economically profitable activity. The income from the activity is therefore well above the expenditure. In addition, there is a financial flow transfer of 2067 FCFA / ton from the rest of the economy to the ginners. The ginning has a comparative advantage. It is cheaper to use domestic resources to process cotton locally than to import it.

Also, with an Effective Protection Coefficient (EPC) and a Nominal Protection Coefficient (NPC) of just over 1, it can be said that the ginning activity enjoys joint protection on the export selling price of cotton fiber and on tradable inputs. The ginners benefit from an implicit subsidy linked to the policy of transformation of agricultural raw materials initiated by the Ivorian State.

Table VII: Competitiveness and economic efficiency indicators of the Policy Analysis Matrix (PAM) of the ginning of seed cotton

\begin{tabular}{|ll|l|l|}
\hline $1-$ & Private profit & $\mathrm{D}=\mathrm{A}-\mathrm{B}-\mathrm{C}$ & 16385 \\
\hline $2-$ & Private Cost Ratio & $\mathrm{PCR}=\mathrm{C} /(\mathrm{A}-\mathrm{B})$ & 0.91 \\
\hline $3-$ & Social profit & $\mathrm{H}=\mathrm{E}-\mathrm{F}-\mathrm{G}$ & 14318 \\
\hline $4-$ & Domestic Resource Cost Ratio & $\mathrm{DRC}=\mathrm{G} /(\mathrm{E}-\mathrm{F})$ & 0.92 \\
\hline $5-$ & Social Cost Ratio & $\mathrm{SCR}=(\mathrm{F}+\mathrm{G}) / \mathrm{E}$ & 0.96 \\
\hline $6-$ & Transfers & $\mathrm{L}=\mathrm{I}-\mathrm{J}-\mathrm{K}$ & 2067 \\
\hline $7-$ & Nominal Protection Coefficient & $\mathrm{NPC}=\mathrm{A} / \mathrm{E}$ & 1.08 \\
\hline $8-$ & Effective Protection Coefficient & $\mathrm{EPC}=(\mathrm{A}-\mathrm{B}) /(\mathrm{E}-\mathrm{F})$ & 1.06 \\
\hline $9-$ & Profitability Coefficient & $\mathrm{PC}=\mathrm{D} / \mathrm{H}$ & 1.14 \\
\hline $10-$ & Subsidy Ratio to Producers & $\mathrm{SRP}=\mathrm{L} / \mathrm{E}$ & 0.01 \\
\hline $11-$ & Equivalent Subsidy to producers & $\mathrm{ESP}=\mathrm{L} / \mathrm{A}$ & 0.01 \\
\hline
\end{tabular}




\subsection{Competitiveness of the spinning sub-sector}

\section{Policy Analysis Matrix (PAM) of spinning companies}

The financial profit (D) and the economic profit $(\mathrm{H})$ of spinners are superior to 0 according to the Table VIII. The cotton spinning business is financially and economically profitable. It also contributes to the economic growth of the locality and has a comparative advantage. The farmer has every interest in encouraging the processing of cotton fiber. However, positive net transfers $(\mathrm{J})$ and $(\mathrm{K})$ indicate that tradable inputs and domestic factors are taxed.

Table VIII: PAM of spinning for a ton of cotton fiber

\begin{tabular}{|c|c|c|c|c|}
\hline & & Inpu & $\operatorname{cost}$ & \\
\hline & Revenue & Tradable inputs & Domestic factors & Protit \\
\hline Private prices & $\begin{array}{l}\text { A } \\
\\
971300\end{array}$ & 763000 & 193569 & $\begin{array}{ll}\mathrm{D} & \\
& 14 \\
731 & \\
\end{array}$ \\
\hline Social prices & $\begin{array}{ll}\text { E } & \\
& 950200\end{array}$ & $\begin{array}{l}F \\
700\end{array}$ & 189453 & $\begin{array}{ll}\mathrm{H} & \\
047 & \\
\end{array}$ \\
\hline Net transfers & $\begin{array}{lll}\text { I } & & \\
& 21100 \\
\end{array}$ & 16300 & 4116 & $\mathrm{~L}$ \\
\hline
\end{tabular}

\section{Competitiveness and economic efficiency indicators of the Policy Analysis} Matrix (PAM) of the spinning companies

When reading Table IX, the subsector of the spinning has a Private Cost Ratio (PCR), a Domestic Resource Cost Ratio (DRC) and a Social Cost Ratio (SCR) less than 1. The spinning is a financially and economically profitable activity. The revenue from the activity is well above the expenditure. The spinners efficiently allocate their resources. It is cheaper in domestic resources to locally process cotton fiber than to import it. Moreover, with a net transfer valued at 684 FCFA / ton and positive, one can retain that the spinners benefit from a subsidy. This economic policy measure is confirmed by an Effective Protection Coefficient (EPC) and a Nominal Protection Coefficient (NPC) higher than 1. In fact, spinners benefit from joint protection on the selling price for the export of yarns and on tradable inputs. This result is identical to those obtained by Mariem (2013) in a study on the evaluation of the export potential of cotton and textiles in Cote d'Ivoire. 
Table IX: Competitiveness and economic efficiency indicators of the Policy Analysis Matrix (PAM) of the spinning companies

\begin{tabular}{|ll|l|l|}
\hline $1-$ & Private profit & $\mathrm{D}=\mathrm{A}-\mathrm{B}-\mathrm{C}$ & 14731 \\
\hline $2-$ & Private Cost Ratio & $\mathrm{PCR}=\mathrm{C} /(\mathrm{A}-\mathrm{B})$ & 0.93 \\
\hline $3-$ & Social profit & $\mathrm{H}=\mathrm{E}-\mathrm{F}-\mathrm{G}$ & 14047 \\
\hline $4-$ & Domestic Resource Cost Ratio & $\mathrm{DRC}=\mathrm{G} /(\mathrm{E}-\mathrm{F})$ & 0.93 \\
\hline $5-$ & Social Cost Ratio & $\mathrm{SCR}=(\mathrm{F}+\mathrm{G}) / \mathrm{E}$ & 0.99 \\
\hline $6-$ & Transfers & $\mathrm{L}=\mathrm{I}-\mathrm{J}-\mathrm{K}$ & 684 \\
\hline $7-$ & Nominal Protection Coefficient & $\mathrm{NPC}=\mathrm{A} / \mathrm{E}$ & 1.02 \\
\hline $8-$ & Effective Protection Coefficient & $\mathrm{EPC}=(\mathrm{A}-\mathrm{B}) /(\mathrm{E}-\mathrm{F})$ & 1.02 \\
\hline $9-$ & Profitability Coefficient & $\mathrm{PC}=\mathrm{D} / \mathrm{H}$ & 1.05 \\
\hline $10-$ & Subsidy Ratio to Producers & $\mathrm{SRP}=\mathrm{L} / \mathrm{E}$ & 0.01 \\
\hline $11-$ & Equivalent Subsidy to producers & $\mathrm{ESP}=\mathrm{L} / \mathrm{A}$ & 0.01 \\
\hline
\end{tabular}

\section{2-4 Competitiveness of the crushing subsector}

\section{Policy Analysis Matrix (PAM) of the crushing subsector}

According to Table $\mathrm{X}$, the crushing activity of the cotton seed generates a positive and interesting financial and economic profit. The activity is profitable for the crushers and also contributes to the economic growth of the locality. The transfers $(\mathrm{J})$ and $(\mathrm{K})$ are positive. This means that tradable and non-tradable factors are taxed.

Table X: PAM of crushers for a ton of cotton seed

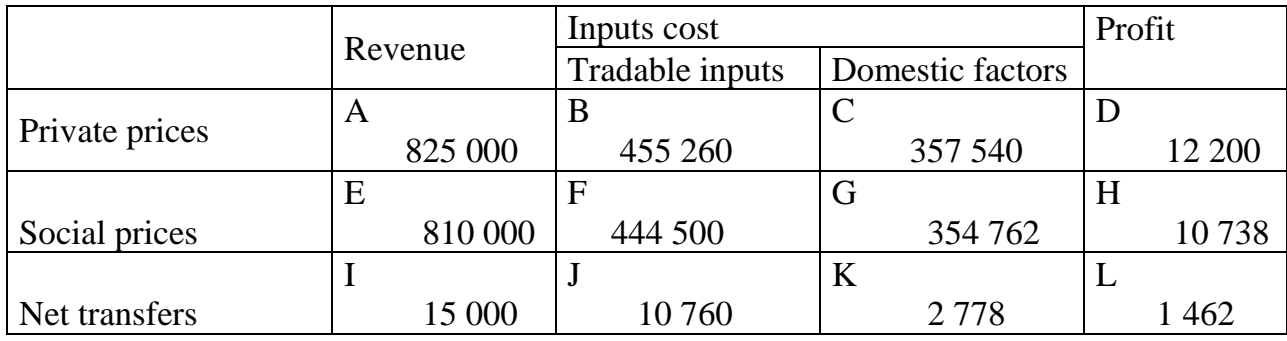

\section{Competitiveness and economic efficiency indicators of the Policy Analysis} Matrix (PAM) of the seed crushing sub-sector

Table XI shows that the Private Cost Ratio (PCR), the Social Cost Ratio (SCR) and the Domestic Resource Cost Ratio (DRC) of the crushers are respectively less than 1 . As a result, the activity is financially and economically profitable. The revenue from the crushing activity, which largely exceeds the expenditures made. The spinners efficiently allocate their resources. There is a transfer of financial flows of 1462 FCFA / ton from the rest of the economy to the crushers and thus the crushers benefit from an implicit subsidy. Furthermore, the crushing subsector has a comparative advantage with regard to the results recorded in the table below. It will be remembered that it is less expensive than domestic resources to locally transform the cotton seed than to import it. This economy policy measure is 
confirmed by an Effective Protection Coefficient (EPC) and a Nominal Protection Coefficient (NPC) slightly higher than 1. Crushing benefits from joint protection on the export selling price of cottonseed oil and on tradable Inputs. These results are similar to those obtained by Anne (2016).

Table XI: Competitiveness and economic efficiency indicators of the Policy Analysis Matrix (PAM) of crushing of the cotton seed

\begin{tabular}{|ll|l|l|}
\hline $1-$ & Private profit & $\mathrm{D}=\mathrm{A}-\mathrm{B}-\mathrm{C}$ & 12200 \\
\hline $2-$ & Private Cost Ratio & $\mathrm{PCR}=\mathrm{C} /(\mathrm{A}-\mathrm{B})$ & 0.97 \\
\hline $3-$ & Social profit & $\mathrm{H}=\mathrm{E}-\mathrm{F}-\mathrm{G}$ & 10738 \\
\hline $4-$ & Domestic Resource Cost Ratio & $\mathrm{DRC}=\mathrm{G} /(\mathrm{E}-\mathrm{F})$ & 0.97 \\
\hline $5-$ & Social Cost Ratio & $\mathrm{SCR}=(\mathrm{F}+\mathrm{G}) / \mathrm{E}$ & 0.99 \\
\hline $6-$ & Transfers & $\mathrm{L}=\mathrm{I}-\mathrm{J}-\mathrm{K}$ & 1462 \\
\hline $7-$ & Nominal Protection Coefficient & $\mathrm{NPC}=\mathrm{A} / \mathrm{E}$ & 1.02 \\
\hline $8-$ & Effective Protection Coefficient & $\mathrm{EPC}=(\mathrm{A}-\mathrm{B}) /(\mathrm{E}-\mathrm{F})$ & 1.01 \\
\hline $9-$ & Profitability Coefficient & $\mathrm{PC}=\mathrm{D} / \mathrm{H}$ & 1.14 \\
\hline $10-$ & Subsidy Ratio to Producers & $\mathrm{SRP}=\mathrm{L} / \mathrm{E}$ & 0.001 \\
\hline $11-$ & Equivalent Subsidy to producers & $\mathrm{ESP}=\mathrm{L} / \mathrm{A}$ & 0.001 \\
\hline
\end{tabular}

\section{Conclusion}

The main objective of the study is to assess the economic competitiveness of the cotton industry in Cote d'Ivoire. On the basis of the results, it appears that each actor in the sector benefits financially. The cotton sector is competitive and has a comparative advantage. All actors have an interest in continuing their activities. It is cheaper to produce and process cotton locally. In addition, these actors benefit from an implicit subsidy and protection through agricultural policy of Cote d'Ivoire. Nevertheless, the sector is suffering the effects of disproportionate competition from Asian countries. Thus, to improve the competitiveness of the cotton sector in Cote d'Ivoire, agricultural policies must favor a better allocation of productive resources by taking into account the determinants of competitiveness such as prices, the quality of seed cotton, the output and the cost of production.

\section{References}

1. Adegbola P., (2006). Competitiveness of the cashew nut sector in Benin: an analysis of the effects at reference prices. PAPA/INRAB. Article presented at the third edition of INRAB's scientific workshop.

2. Anne G., (2006). Cotton, a commodity profile by the UNCTAD Fund for Agricultural commodity Market Information. United nations conference on trades and development. 21P.

3. Fabio B., (2006). Development of a cotton sector strategy: medium and long-term perspectives, diagnosis and orientation proposals Cote d'Ivoire. Final diagnosis report. 144P. 
4. FAO, (2005). The value chain approach: analysis at reference prices. Agricultural Policy support service, Policy Assistance Division, FAO, $74 \mathrm{p}$.

5. Gnonna S. (2007). Analysis of determinants of the efficiency of cotton production in Benin. Master Thesis, University Academy Leuven, 78p.

6. Hubert S., (2011). Impact of cotton dynamics on rural development, case study of Korhogo region, north and central Cote d'Ivoire, Biotechnology, Agronomy, Society and Environment, 10 (4); 21p.

7. Kouakou K., (2014). Diagnostic of the performance of cotton production in Cote d'Ivoire, journal of theoretical and applied economics, 4 (1), pp75-96.

8. Mariem N., (2013). Evaluation of the export potential of cotton and textiles in Cote d'Ivoire. Institutional and operational support for improving the business environment and enhancing the competitiveness of Cote d'Ivoire's exports, 70p.

9. Monke E. et Pearson, (1989). "The policy Analysis Matrix for Agricultural Development", the role of agricultural policy analysis. Cornell University Press. Ithaca and London, 267p.

10. Simplice Y., (2013). Liberalization of the cotton sector in Cote d'Ivoire fifteen years later: special and organizational footprint. Five continents, 3 (7), pp 5-17. 